\title{
38. Bilinmeyen bir şair: Hammâd ve Divançesi
}

\section{Eda TOK'}

\begin{abstract}
APA: Tok, E. (2021). Bilinmeyen bir şair: Hammâd ve Divançesi. RumeliDE Dil ve Edebiyat
\end{abstract} Araştırmaları Dergisi, (22), 616-640. DOI: 10.29000/rumelide.897073.

\section{$\ddot{\mathbf{O z}}$}

Klasik Tük edebiyatı geleneği bünyesinde pek çok şair yetişmiş ve genel itibariyle gerek yaşadıkları dönemlerde gerekse daha sonraki dönemlerde yazılan biyografik kaynaklarda kendilerine yer bulabilmişlerdir. Ancak geniş bir şair kadrosuna sahip olan klasik Türk edebiyatı tarihinde ismi tezkirelerde ve biyografik kaynaklarda anılmayan, henüz tespit edilememiş pek çok şair de bulunmaktadır. İsmi kaynaklarda geçmeyen ve hayatı hakkında bilgilere ulaşılamayan şairlerden biri de Hammâd'dır. Şiirlerinde Hammâd mahlasını kullanan şairin asıl isminin ne olduğu, nerede doğduğu ve nasıl bir yaşam sürdüğüne dair bilgilere ulaşılamamıştır. Hammâd'ın şimdilik bilinen tek eseri divançesidir. Şairin divançede yer alan şiirlerinde de hayatına dair bilgilere tesadüf edilememiştir. Bu çalışmada tarafımızca tespit edilen Hammâd Divançesi tanıtılmış ve divançenin çevriyazılı metni oluşturulmuştur. Divançede 33 gazel (2 gazel eksik) ve 1 müseddes bulunmaktadır. Hammâd’ın ilgili şïrleri şekil ve muhteva bakımından genel olarak değerlendirilmiştir. Şairin şiirleri incelendiğinde ise şiirlerinde klasik Türk şiiri geleneğinin genel muhtevasına bağlı kaldığı, klasik Türk şiirinin aşk, âşı, sevgili, rakip, şarap, güzellik, gül-bülbül, tarihî-efsanevi şahsiyetler, tabiat, talihten şikâyet gibi ortak malzemelerini başarılı bir biçimde kullandığı görülmüştür. Şiirlerinde çoğunlukla âşıkâne üslup tercih eden şairin dili, sade ve akıcıdır. Bu çalışma ile klasik Türk şiirinin bilinmeyen bir temsilcisi olan Hammâd ve divançesi tanıtılarak ilim dünyasının istifadesine sunulmuştur.

Anahtar kelimeler: Klasik Türk edebiyatı, metin neşri, Divançe

\section{An unknown poet: Hammad and his Divanche}

\begin{abstract}
A number of poets have grown within the scope of classical Turkish literature tradition and commonly they could gain ground for themselves in biographical issues written both in the era they had lived and in the forthcoming periods. Yet, in our history of classical Turkish literature that has a wide range of poets, there are a lot of poets whose name is not referred in collected biographies and biographical issues, and poets who have not been confirmed. One of those poets whose name is not mentioned in issues and about whom any information is attained is Hammad. About the poet who used the pseudonym Hammad in his poetry, no information could be achieved on his real name, his place of birth and what kind of a living he leaded. As for now, his only known work is his Divanche. Any information about his life is not encountered in his poems in Divanche, too. In this study, Hammad Divanche that is confirmed by us, is described and its transcripted text is organised. In the Divanche, there are 33 ghazels (lacking 2 ghazels) and 1 müseddes. Hammad's related poems have been evaluated in terms of shape and content. As the poems of the poet are examined, it is
\end{abstract}

Dr. Öğr. Üyesi, Düzce Üniversitesi, Fen Edebiyat Fakültesi, Türk Dili ve Edebiyatı Bölümü (Düzce, Türkiye), tok_eda@hotmail.com, ORCID ID: oooo-0002-9939-0154 [Araştırma makalesi, Makale kayıt tarihi: 10.02.2021-kabul tarihi: 20.03.2021; DOI: 10.2900o/rumelide.897073]

Adres

RumeliDE Dil ve Edebiyat Araşttrmaları Dergisi Osmanağa Mahallesi, Mürver Çiçeği Sokak, No:14/8

Kadıköy - İSTANBUL / TÜRKIYE 34714 e-posta: editor@rumelide.com

tel: +90 $5057958124,+902167730616$
Address

RumeliDE Journal of Language and Literature Studies

Osmanağa Mahallesi, Mürver Çiçeği Sokak, No:14/8

Kadıköy - ISTANBUL / TURKEY 34714

e-mail: editor@rumelide.com,

phone: +90 $5057958124,+902167730616$ 
found out that he abides by the common content of the classical Turkish poetry tradition, and that, in his poems, he used common items such as love, lover, beloved, rivalry, wine, beauty, rosenightingale, historical- fabulous characters, nature, and complaint about fortune. The literary language of the poet who mostly preferred an affectionate style, is unsophisticated and fluent. With his study, as an unknown representative of classical Turkish poetry, Hammad and his Divanche are introduced and presented to the benefit of the world of science.

Keywords: Classical Turkish literature, text puplication, Divanche

\section{Giriş}

Divan edebiyatı geleneği çerçevesinde yetişen pek çok şair genel itibariyle gerek yaşadığı dönemde gerekse daha sonraki dönemlerde yazılan biyografik kaynaklarda kendilerine yer bulmuşlardır. Ancak edebiyat tarihimizde ismi tezkirelerde ve biyografik kaynaklarda anılmayan çok sayıda şair bulunmaktadır. Bu bakımdan divan şairlerinin tamamının tespit edilebildiğini söylemek oldukça güçtür. Bilhassa son dönem çalışmalarında, kaynaklarda ismi anılmayan ancak şiir mecmualarında şiirleriyle dikkat çeken şairler de tespit edilmiş ve edilmektedir. İsmi kaynaklarda geçmeyen, hayatı hakkında bilgilere ulaşılamayan ve hâlen tanınmayan şairlerden biri de Hammâd'dır. Kaynaklarda anılmayan Hammâd'ın asıl ismi, nerede doğduğu ve yaşantısı hakkındaki bilgilere ulaşılamamıştır. Şimdilik Hammâd'ın bilinen tek eseri divançesidir. Şairin divançesi incelendiğinde de hayatıyla ilgili bilgiler saptanamamıştır. Hammâd Divançesi, Yapı Kredi Sermet Çifter Araştırma Kütüphanesi, Nadir ve Yazma Eserler Bölümü, 035771/1 demirbaş numarası ile kayıtlıdır. Eserin kataloglara kayıtlı başka nüshası tespit edilememiştir.

\section{Nüsha tavsifi}

Nüsha, Ta'lik hatla, Türkçe, 205x15o (140x90) mm. ölçüsünde, 2 sütunlu, 12a-21b² varakta, 14 satırll, elvan kâğıda yazılmıştır. Mehmed b. İbrahim tarafından 1238 (1822-1823) tarihinde istinsah edilmiştir. Nüshanın sonunda “Kad temmete hazihi'l-ḳașidetü’l-Ḥammād, 'ābīd eż'afu’z-ża'īf Muḥammed e'l-faḳkare'l-fuḳarā veled-i İbrahim Beg fi'l-yevmi-cum'a fi vaḳt-i zuhr. Gafera'l-lāhu lehumā fi'd-dāri ve seḳule iḥsānehumā fi rūz-i hișāb. Yā Allāh, yā Allāh, yā Allāh bi-tāriḥu'n-nebi sene[-i Muharrem] 1238.” şeklinde temmet kaydı bulunmaktadır. Kahverengi meşin, kapak üzerlerinde ortadan ve köşelerden ikişer basma çizgi, şirâzesi dağılmış cilt içindedir. 1a'da iki değişik renkte boya ile yapılmış dâire tezhiblidir. İki kırmızı çizgi cetvellidir. Nüshanın her yapră̆ının b sayfasının sol alt köşesinde çoban kaydı bulunmaktadır. Nüshanın 14b, 15a, 16a, 16b, 17a, 17b, 18a, 20a, 20b, 21a, 21b varaklarında derkenarlar mevcuttur.

\section{Baş:}

Ey māh u mihri dā’ir iden āsumān ara

Yā meşyete'n-nücūme ve yā rāfi'a's-semā

\section{Son:}

Ḥammād renc-i humār eyledi dilgīr

Ḳıl gel aña bir cām-1 ferāḥ-bahş̧ ne tedbīr

2 Kütüphane kataloğuna Divançe 1b-21b varakları olarak kaydedilmiştir. Adres | Address

RumeliDE Dil ve Edebiyat Araştırmaları Dergisi $\quad$ RumeliDE Journal of Language and Literature Studies Osmanağa Mahallesi, Mürver Çiçeği Sokak, No:14/8 Osmanağa Mahallesi, Mürver Çiçeği Sokak, No:14/8 Kadıköy - İSTANBUL / TÜRKIYE 34714 Kadıköy - ISTANBUL / TURKEY 34714 e-posta: editor@rumelide.com e-mail: editor@rumelide.com, tel: +90 505 7958124, +90 2167730616 phone: +90 505 7958124, +90 2167730616 
Ḳurbānıñ olam sö[y]leme munca bu te'hīr

Firșat var iken elde gözüm eyleme taḳ̣īr

Doldur içelim sāḳi-i gül-çehre piyāle

Ḳoyma yazuḳum kim ġam-1 devrān beni ala

\section{Divançenin şekil ve muhteva özellikleri}

Divançe'de 2'si eksik olmak üzere toplam 33 gazel ve 1 müseddes-i mütekerrir bulunmaktadır. 31 tam gazelin 13'ü 7 beyitten, 7'si 6 beyitten, 5'i 8 beyitten, 2'si 9 beyit, 2'si 10 beyitten, 1'i 12 beyit, 1'i 5 beyitten oluşmaktadır. Gazellerin çoğunlukla beş beyitten daha fazla olduğu dikkat çekmektedir. Gazeller, nüshada vav (و) harfine kadar alfabetik sirayla, vav (و)'dan sonra ise sirasiyla 1 re ()), 1 he ( ه), 3 re (ر), 1 ye (ى), 1 nun (ن) şeklinde yer almaktadır. Nüshada zı ( $($ ) ve 'ayın ( $)$ ) harflerinden gazel bulunmamaktadır. Müstensihin tı (b) harfinde gazelin matla beytini yazdıktan sonra gazele gayın (غ) harfi ile devam etmesi, divançede diğer tüm harflerden şiirler bulunması bu durumun müstensihin dikkatsizliğinden kaynaklanabileceğine işaret etmektedir. Gazellerin harflere göre sayı dağılımı şu şekildedir:

\begin{tabular}{|c|c|c|c|c|c|c|c|c|c|}
\hline elif ( 1 ) & 2 & hl $(\dot{z})$ & 1 & şin (ش) & 1 & kaf (ق) & 1 & $\operatorname{vav}(g)$ & 1 \\
\hline be (ب) & 1 & dal (د) & 1 & sad (ص) & 1 & kef (ك) & 1 & ye (s) & 1 \\
\hline te (ت) & 1 & zel (ذ) & 1 & dat (ض) & 1 & lâm (J) & 1 & & \\
\hline se (ث) & 1 & $\operatorname{re}(ر)$ & 5 & ti (b) & 1 & $\operatorname{mim}($ ) & 1 & & \\
\hline $\operatorname{cim}(ج)$ & 1 & ze $(j)$ & 1 & gayın $(\dot{\xi})$ & 1 & nun (ن) & 2 & & \\
\hline ha $(\tau)$ & 1 & sin (س) & 1 & fâ (ف) & 1 & he (ه) & 2 & & \\
\hline
\end{tabular}

Hammâd şiirlerinde genel olarak klasik Tük şiirinde sık kullanılan vezinlerini kullanmayı tercih etmiştir Hammâd'ın şiirlerinde kullandığı aruz kalıpları ve kullanım sıklığı ise şu şekildedir:

\begin{tabular}{|c|c|c|}
\hline Bahirler & Vezinler & Şiir Sayısı \\
\hline \multirow{3}{*}{ Remel } & Fâ'ilâtün Fâ‘ilâtün Fâ‘ilâtün Fâ‘ilün & 15 \\
\hline & Fe'ilâtün Fe'ilâtün Fe'ilâtün Fe'ilün & 4 \\
\hline & Fâ'ilâtün Fâ'ilâtün Fâ‘ilün & 1 \\
\hline \multirow{3}{*}{ Hezec } & Mefâ‘îlün Mefầîlün Mefâ‘̂̂lün Mefâ‘îlün & 8 \\
\hline & Mef'ûlü Mefâ‘̂̀lün Mef'ûlü Mefầ̂llün & 1 \\
\hline & Mef'ûlü Mefâ‘̂̂lü Mefầ̂̀lü Fe ûlün & 2 \\
\hline Muzâri & Mef'ûlü Fâ‘ilâtü Mefâ‘̂̂lü Fâ'ilün & 1 \\
\hline Hafif & Fe ilâtün Mefā‘ilün Fe ilün & 1 \\
\hline
\end{tabular}

Rubâî vezniyle yazılan manzumeler dört mısradan fazla olmazken 17. yüzyılda Şeyhülislâm Yahyâ Efendi, rubâî vezniyle bir gazel yazarak yenilik göstermiştir (Tâhirü’l-Mevlevî, 2019:165-166). Şairlerin farklı nazım şeklilerini rubâî vezinleriyle kaleme aldıkları örnekler mevcuttur. Özellikle Gazel Rubâî

\footnotetext{
\begin{tabular}{r|l} 
Adres & Address \\
RumeliDE Dil ve Edebiyat Araşttrmaları Dergisi & RumeliDE Journal of Language and Literature Studies
\end{tabular} 
başlığı altında yazılan bazı manzumeler şekil olarak gazel; vezin olarak ise sadece rubâî vezinleriyle yazıldıklarından bu adlarla kaydedilmiştir. 17. yüzyll şairlerinden Arşî ve Tâlib (ö. 1085/1674); 18. yüzyıl şairlerinden Kânî (ö. 1206/1791) ve 19. yüzyll şairlerinden Ömer Şevkî (ö. 1268/1852) Gazel Rubâî kaleme alan şairlerdendir (Çalka, 2014: 208-209). Hammâd'ın 12 numaralı gazeli de Gazel Rubâî örneğidir. Gazelde mısralara göre değişen rubâî vezinleri kullanılmıştır. Şair, "Mef'ûlü Mefấîlün Mef'ûlün Fâ", "Mef'ûlü Mefâ‘îlü Mefâ‘îlün Fâ‘", "Mef'ûlü Mefấilün Mefâ‘îlün Fâ" rubâî vezinlerini kullanmıştır.

Hammâd şiirlerinde çoğunlukla klasik Türk şiirinde çok rağbet edilen mürdef kafiyeyi kullanmayı tercih etmiştir. Şair şiirlerinde ahengi sağlayan bir unsur olarak "-sin (G. 33), -dan (G.24)" gibi ekten meydana gelen redifleri, "âşık (G.20), çarh (G.8)" gibi tek kelimeden meydana gelen redifleri, "-dan güzel (G.22), -dır senin (G.21)" gibi ek ve kelimeden meydana gelen redifleri, "tek leziz (G.10), ne nisbetdir (G.G29)” gibi birden fazla kelimeden meydana gelen redifleri kullanmıştır.

Hammâd şiirlerinde klasik Türk şiiri geleneğinin genel muhtevasına bağlı kalmıştır. Şair şiirlerinde aşk, âşık, sevgili, rakip, şarap, güzellik, gül-bülbül, şem-pervane, tarihî-efsanevi şahsiyetler, tabiat, talihten şikâyet gibi konuları işlemiştir. Şair, sevgilinin güzellik vasıfları, âşı̆̆ın çaresizliği, sevgiliden ayrı kalmanın gamı, aşk, rind-zahid çatışması gibi hemen hemen her divanda karşılaşılabilecek konuları çeşitli edebi sanatlarla söz konu etmiştir. Şair, şiirlerinde genel olarak âşıane ve rindane duyguları terennüm etmiştir. Hammâd'ın şiirlerinde yer yer Arapça ifadelere, bölümlere yer vermesi onun Arapçaya hâkim olduğuna da işaret etmektedir. Şairin şiirlerinde Arapça bölümler dışında genel itibariyle külfetsiz, sade ve anlaşılır bir dil kullandığı görülmektedir.

\section{Sonuç}

Hammâd'a dair tezkirelerde ve diğer biyografik kaynaklarda herhangi bir bilgi bulunmamaktadır. Hammâd'ın şimdilik bilinen tek eseri divançesidir. Bu divançede 33 (2'si eksik) gazel ve 1 müseddes-i mütekerrir bulunmaktadır. Şair, şiirlerinde külfetsiz, sade ve anlaşılır bir dil kullanmıştır. Hammâd şiirlerinde klasik Türk şiiri geleneğinin genel muhtevasına bağlı kalmış, klasik Türk şiirinin aşk, âşık, sevgili, rakip, şarap, güzellik, gül-bülbül, tabiat, talihten şikâyet gibi ortak malzemelerini başarılı bir biçimde kullanmıştır. Şiirlerinde genel itibariyle âşıkâne üslup tercih etmiştir. Şair, şiirlerinde divan şiirinde sık kullanılan vezinlerini kullanmıştır.

Bu çalışma ile klasik Türk edebiyatının bilinmeyen temsilcilerinden biri olan Hammâd ve divançesi tanıtılarak ilim dünyasının istifadesine sunulmuştur. Böylece klasik Türk şiirinin bilinmeyen bir temsilcisi ve eseri daha tanıtılarak bu alanda yapılacak olan yeni çalışmalara da zemin hazırlanmıştır.

\section{Metnin teşkilinde takip edilen yöntem ve bazı teknik hususlar3}

Hammâd Divançesinin çevriyazılı metni hazırlanırken şu hususlar göz önünde bulundurulmuştur:

- Divançe'deki şiirlerin sıralanışına sadık kalınarak şiirler numaralandırılmıştır.

- Nüshanın istinsah tarihi 19.yüzyıl olduğu için metin düzlük yuvarlık uyumu bakımından günümüze yaklaştırılmıştır.

3 Çevriyazılı metin oluşturulurken İsmail Ünver'in "Çevriyazıda Yazım Birliği Üzerine Öneriler” (Ankara Üniversitesi DTCF Türkoloji Dergisi, C XI, S 1, 1993 s. 51-89.) ve Fatih Köksal'ın "Metin Neşrinin Ana Esasları” (Eski Türk Edebiyatında Tenkit ve Teori, İstanbul: Kesin Yayınları, 2017, s. 17-45.) adlı çalışmalarından yararlanılmıştır.

Adres | Address

RumeliDE Dil ve Edebiyat Araşttrmaları Dergisi $\quad$ RumeliDE Journal of Language and Literature Studies Osmanağa Mahallesi, Mürver Çiçeği Sokak, No:14/8 Osmanağa Mahallesi, Mürver Çiçeği Sokak, No:14/8

Kadıköy - İSTANBUL / TÜRKIYE 34714 Kadıköy - ISTANBUL / TURKEY 34714 e-posta: editor@rumelide.com

e-mail: editor@rumelide.com

tel: +90 $5057958124,+90216773$ o 616 phone: +90 505 7958124, +90 216773 o 616 


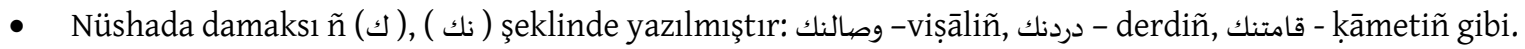

- Nüshada bunca- munca, baḳmak- baḩmak gibi kullanımlarda metne bağlı kalınmıștır.

- Her türlü metin tamiri köşeli ayraç [ ] içinde gösterilmiştir.

- Müstensih hatasıyla yanlış yazılan bazı kelimeler asli imlalarıyla metne alınmıştır: “ سيقل - wayḳal, žāt, مظمون - mażmūn" gibi.

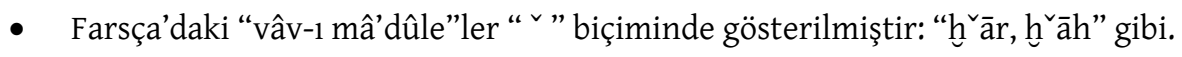

- Metin içerisinde geçen "dürr, kadd” gibi şeddeli kelimeler vezne göre tek veya çift ünsüzle okunmuştur.

- Farsça ikilemelerin ortasına getirilen ekler kısa çizgi (-) ile ayrılmıştır: "ser-be-ser, dem-be-dem" gibi.

- Ön ekler, edatlar eklendikleri kelimeden kısa çizgi (-) ile ayrılmıştır: "bī-çāre, bīi-cān, hem-dem" gibi.

- Farsça son eklerin yazımında; mastarın geniş zaman kökünden oluşan ekler kelimeden ayrı, diğerleri eklendikleri kelimeye bitişik yazılmıştır: "merdüm-küş, cān-bahş, dil-ber; mehveş, gülistān, lālezār" gibi.

- İki isimden oluşan birleşik sıfatlar ve birleşik isimler kısa çizgi (-) ile ayrılmıştır: "bed-gümān, ḩoşlehçe" gibi.

- Atıf vavları kalınlık-incelik uyumu göz önüne alınarak “u-ü/ vü” şeklinde okunmuştur.

- Farsça isim ve sıfat tamlamalarında tamlayan ve tamlanandan sonra ses uyumu dikkate alınarak 1-i/ y1-yi yazılmıştır.

\section{Metin}

\section{[12a]}

\section{Bismillāhirraḥmānirraḥim ve bihi nestainu Rabbi yessirnā}

1

\section{Mef’ūlü Fā‘ilātü Mefā‘ịlü Fā'ilün}

1. Ey māh u mihri dā'ir iden āsumān ara

Yā meşyete'n-nücūme ve yā rāfi'a's-semā

2. Şevḳiñle devr ider gece gündüz ay u gün

Mihriñle rakṣ ider heme zerrāt dā’imā

3. Ferd-i yegāne lāsın yoḳdur saña nazịir zāàt

Yā men leke'l-teferrüd bi'l-mecdi ve'l-ulā

4. Ente'l-lezī ḥalaḳte cemī'e'l-mükevvenāt 
Min feyżike'l-‘amīm ve evcedtu kullehā

5. Eşyā tamām ḥādis ü sensen ḳadīm bes

Eşyāda ancaḳ oldı müsellem beḳā saña

6. Ümīdvār-1 luṭfunum ey Kirdgār-1 fażl

Kahr ile benden eyleme teșhīṣ-i mācerā

7. Maḥv eyle nāme-i ‘amelden günāhını

Rūz-ı cezā baña raḳamı fażlıñ it 'ațā

8. Merdūd kilma mes'elemi kim kerīmsin

Redd-i su'āl ehl-i keremden degül revā

9. Bol șükr [ü] hamd kim aña luțfuñ olup refik

Hammād oḳur hemīșe saña midhat ü șenā

2

\section{Fā‘ilātün Fā'ilātün Fā'ilātün Fā'ilün}

1. Ey ḩabib-i ber-güzīn ü hāllkẹ-1 'arż u semā

Eylemiş Yezdān seni ser-ḩayl-i fevc-i enbiyā

2. Z Zāàt-1 pākiñdir seniñ ìcād-ı 'ālemden murād

Yoḳsa ke’l-ma‘dūmdur mevcūd-1 ‘ālem küllehā

3. İktiżā-yı hikmetiyle Kirdgār itdi seni

Manșib-i ‘izz ü şerefde mā-sivallāhdan sivā

[12b]

4. Seyyid-i kevneyn-i fahrr-i mürselīn bolduñ yakīin

Sensin ancak enbiyā vü evliyāya pișsā

5. Sāre ey min ḳabli 'aynun ḩayru mevcūd[in] kezā

Hākezāa min ba'di ḥüsnün ḥaşre mișluh lābüdā

6. Ḥabbezā ni'mel-beşīru merhabā ni'me'n-nazīr

Hem beşīi-i etḳiyāsın hem naẓīr-i asfiyā

7. Lā-tedernì elyesā min luṭfike yevmü'l-müzāb

Yā şefi'a'l-müznibīn eltaf binā veşfi' lenā

8. Terk-i sünnet cürmini 'afv eyle benden yā resūl

Rū-siyāh u şermsārem bir terahhumum ḳ1 baña

9. Yā nebī Hammād-1 pür-'ișyān saña dutmuş ümīd

Ḳılma maḥrūm-1 şefāatat anı sen rūz-ı cezā 


\section{Fā‘ilātün Fā'ilātün Fā'ilātün Fā'ilün}

1. Māh-1 rūyuñ üzre kim olmuş ḳara zülfüñ hicāb

Gūyiyā huūrşīddir setr eylemiş anı seḥāb

2. Görgeç ol ebrūlarıñ țarḥın meh-i nev ḩam bulur

İnfi'āl eyler görende mihr-i rūyuñ āfitāb

3. Görmesün ruhsā̄ıñn her manẓarā-yı māh-rū

İtme hūūşīd-i cemāliñde gözim def'-i nikāb

4. Her ne bī-dād itse hoșdur rāḥat-ı cāndur baña

Eylemen ol ġamze-i merdüm-küşüñden ictināb

5. S S Su gibi her dem ḳılur gözden revān hūn-āblar

Oldı bağrım āteş-i hecriñde yanmaḳdan kebāb

6. Eşk seylinden ki her dem gözlerimdendir revān

Ehl-i ‘ālem merdüm-i çeşmim tek olmuş gark-āb

7. Derd-i 'aşḳıñ eyledi Hुammādı göñ[l]ünden ża'if

Ḳıldı ol dil-ḩasteni bī-tāb-ı aḥvālin ḩarāb

[13a]

4

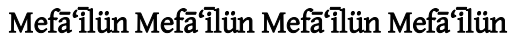

1. Seher gülzāre gir cānā temāşā-yı gülistān it

Çemen gül-ruhların hüusnüñ temāşāsına ḥayrān it

2. Dem-ā-dem bāg ara serv ü șanevber ḳılmasın cilve

Nihāl-i kāmetiñ gülşen sarı bir dem ḩrāmān it

3. Çılḳaydı 'azm-i seyrāna bugün Leyl[i]-ṣıfat yāriñ

Durup Mecnūn-1 şeydā tek gönül seyr-i beyābān [it]

4. Felek her laḩ̣a devr itdiñ benim 'aks-i murādımla

Gel ey zāāim yeter bir dem murādım birle devrān it

5. S Ṣabā gel hasbeten-li'llāh ḳamu ol yāre 'arż eyle

Göñül şerḥin dili aġyārdan maḩfi vü pinhān it

6. Bi-ḥāmdi'llāh ki yitdiñ 'āḳıet ol gül vișāline

Yeter ey ‘andelīb-i dil dahı gel terk-i efgāan [it]

7. Olupdur mihnet-i hicriñde bī-cān haste Hammādıñ

Devā-yı vașlıñ in‘ām ile cānānım bir ihsān it 


\section{Fe'ilātün Fe'ilātün Fe'ilātün Fe'ilün}

1. İdemez serv-i sehī ḳamet-i cānān ile baḥs

‘Ar'ar-1 pā-be-gil ol serv-i ḩrāmān ile baḥs

2. Gül girībānını çāk eyledi bu ḥasretden kim

İdebilmez açılır ol gül-i ḩandān ile baḥs

3. Gül ruyuñ ki aña reşk aparır bāg̀-1 İrem

Ne 'aceb eylese ger ravża-i rı̣̣̂ān ile baḥ

4. Hîç gül-rū saña ey gül olabilmez hem-tā

Kimdir ol kim ide bir kudret-i Yezdān ile bahṣ

5. Mıșr-1 hüsn içre 'azīimim daḩı sendin özge

Hūblardan kim ider Yusūf-ı Ken‘ān ile baḥs

6. Gerçi kūyuñda seniñ bī-ser ü pālar çoḳdur

İdemez kimseye ben bī-ser ü sāmān ile baḥs

[13b]

7. Bāb-1 cengīide mu'ārıż cedel eylerse ne bāk

Ki bu Ḥammād ḳılur hüuccet ü burhān ile baḥs

6

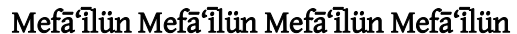

1. Baña raḥm eylemez aḥvālimi ol bī-vefā görgeç

Yine bī-pervādır ol şūh gözüñ bir mübtelā görgeç

2. Bahār-1 hüsne mag̉rūr olma gel 'uşşāḳa cevr itme

Ki bāğ-1 hüsn olur pejmürde bir bād-1 fenā görgeç

3. Vișāliñ birle def' oldı göñülden derd-i hicrānı̃

Bulur șıḥ̣hat belī ehl-i maraż dāru'ş-şifā' gör[geç]

4. Olur her dem żiyā-yı çeşmim efzūn hāāk-i pāyıñdan

Bu rūşendir ki kesb-i nūr ider göz tūtiyā görgeç

5. Ser-i kūyuñ anın dutdum mükerrem el berātından

Ki 'ādetdir beni ādemde ta'zīm āşinā görgeç

6. Begim terk itme luṭf u şefḳatiñ Ḥammād-ı miskinden

Ki ‘ayb olmaz teraḥhum eylemek sulțān gedā görgeç

\footnotetext{
Adres $\mid$ Address

RumeliDE Dil ve Edebiyat Araşttrmalar Dergisi Osmanağa Mahallesi, Mürver Ciçĕgi Sokak, No:14/8 Kadıköy - İSTANBUL / TÜRKIYE 34714 e-posta: editor@rumelide.com RumeliDE Journal of Language and Literature Studies Osmanağa Mahallesi, Mürver Çiçeği Sokak, No:14/8

Kadıköy - ISTANBUL / TURKEY 34714

e-mail: editor@rumelide.com,

tel: +90 505 7958124, +902167730616 phone: +90 505 7958124, +90 2167730616
} 


\section{Fā‘ilātün Fā‘ilātün Fā‘ilātün Fā‘ilün}

1. Zaḥm-1 çeşmiñden bulur peyveste göñlüm inşirāḥ

Bilmezem kiprikleriñ neşter mi yā Rab yā rimāḥ

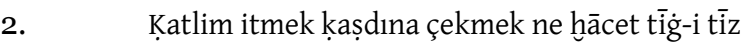

Ḩançer-i nāzıñ yeter ancak ne lāzımdır silāḥ

3. Tịg-i gamzeñ ger diler kan dökmek ey bi-dād-ger

Gel benim ḳanımı nūş olsun saña ḳanım mübāḥ

4. Geh nizā' $\quad$ Gu] ceng eylersin benimle gāh șulh

Geh 'itāb u ḳahr eylersin gehĩ hezl ü ferāḥ

5. Püster-i hecr içre bir dem yuḳu görmez gözlerim

Dem-be-dem bìdār olur her şām sensiz tā șabāḥ

6. Ben ki mest-i cām-ı 'aşḳam sākịnā meyden ne sūd

Eylemez def'-i ḩumārım içsem er biñ cām-ı rāḥ

7. Gerçi bes Hammād sen çekdiñ riyāżet 'āḳıbet

Şükrili'llāh buldı ebvāb-ı murādıñ infitāḥ

[14a]

8

Fā'ilātün Fā'ilātün Fā'ilātün Fā'ilün

1. Kim ki cāhildir olur her dem anıñla yār çarh

Her zemān fażl ehlin eyler h`āa u bì-ḳarār çarh

2. Bilmen üstād-1 ezel āyāna cevr eyler aña

Kim sükūn dersin unutmuş dev[r] ider tekrār çarh

3. Dā’imā pergāl $[\mathrm{s}] \mathrm{iz}$ devr eylemekdür șan'atı

Gerçi dirler kim olur pergālsiz düşvār çarh

4. Muttașil devrān ider başı aşag̉a vājgūn

Eylemezler kār tek bir yerde istiḳrār çarh

5. Bir güneş-ruhsāāe 'āşı̣k $\quad$ benim tek gūyiyā

Kim göz açıp tā seherer her şām olur bīdār çarh

6. $\quad$ Rūz $[u]$ şeb dönmek diler başına bir meh-pārenün

Ġalibā anıñçün olmuş dā'imā devvār çarh

7. Bir gün olmaz derdden dil-şād anıñçün șubh [u] şām

Ḩande-i ālūde-ḩūn eyler müdām iẓhār çarh

8. Bir Mesị̂īi-zāde sevmişdür meger Șan‘ān gibi

Bağlamış ḳavs-i ḳuzaḥdan biline zünnār çarh

\footnotetext{
Adres Address

RumeliDE Dil ve Edebiyat Arasttrmaları Dergisi Osmanağa Mahallesi, Mürver Ciceği Sokak, No:14/8 Kadıköy - İSTANBUL / TÜRKIYE 34714 e-posta: editor@rumelide.com

RumeliDE Journal of Language and Literature Studies Osmanağa Mahallesi, Mürver Çiçeği Sokak, No:14/8

Kadıköy - ISTANBUL / TURKEY 34714

e-mail: editor@rumelide.com

tel: +90 505 7958124, +90 216773 o 616 phone: +90 505 7958124, +90 2167730616
} 
9. Berḳ-i āhından șanursun kim yanar 'aşk odına

Nāle-i feryād ider manend-i mūsīkār çarh

10. 'Aş̧ bārından çekip zaḥmet olupdur nā-tüvān

Bìn-ḳarār efḡān ider her lahz̧a gerdūnvār [çarḥ]

11. Cevri her dem ḳılu[r] 'aks-i mekārim birle devr

Bunca kec-revlikden itmez hiç istiğfār çarh

12. Çekme gam Ḥammād eger devrān zelil itse seni

Kim bu ‘ādetdir ki fażl ehlini eyler h ȟār çarh

9

\section{Fā'ilātün Fā'ilātün Fā'ilātün Fā'ilün}

1. Devrden bulmaz bu maḩūn hāṭirım bir lahẓa şād

Gerdiş-i gerdūn ider her dem baña yüz ġam ziyād

\section{[14b]}

2. N Nişse ḳıldıñ ey felek cānānımı benden cüdā

Ben seni k’itmișdim ey zālim elinden dād dād

3. Cevher-i zāatıñ viṣāl-i dil-bere kābil degül

Ṭynet-i pākiñ[i] it fāş ey rakịib-i bed-nihād

4. 'Aşk meydānında her dem yār içün aġyār ile

Ceng idermin eyle kim küffār ile ehl-i cihād

5. $\quad$ Ey müselmānlar ne tedbīr eyleyem oña fireng

Büt-peresti oldum ammā bilmezem hīç i'tiḳād

6. Diñlemez yahşsı sözüm șanur yaman ol bed-gümān

Gūş idip ag̉yār ḥarfiñ eyler iẓhār-1 'inād

7. Bu felek Ḥammād bir gün ber-murād itmez görim

Devri dönsün Yā Rab anıñ bulmasın hergiz murād

10

\section{Fā‘ilātün Fā‘ilātün Fā‘ilātün Fā‘ilün}

1. Ey dil-i bī-çāare derdiñ derde dermān tek lezīiz

Haste göñlümde gamıñ cismimdeki cān tek lezīiz

2. Ey gül-i handān ser-i kūyuñda yaslanmak baña

‘Andelīb-i zār üçün seyr-i gülistān tek lezīiz

3. Kara günlü ‘āşıḳ-1 reh-i firākıñ şāmda

Şem‘-i rūyuñ şu'lesi ḩūrşīid-i rahş̧ān tek leziī

4. Sākin-i merdūd u bì-cān-1 ser-i kūyuñ seniñ

\footnotetext{
Adres

RumeliDE Dil ve Edebiyat Araşttrmaları Dergisi Osmanağa Mahallesi, Mürver Çiçeği Sokak, No:14/8 Kadıköy - İSTANBUL / TÜRKIYE 34714 e-posta: editor@rumelide.com 
Fi'l-mes el nār ehline firdevs-i rıḍ̂ān tek lezīiz

5. $\quad$ Ey perī-peyker cihānda hem-nişīn olmaḳ saña

Cennet içre șoḥbet-i ḥūr u ġilmān tek lezīiz

6. Gerçi dünyā lezzzetin bir bir ḳamu Ḥammādın

Gördüm ammā görmedim dīdār-1 cān tek leżīz

[15a]

11

\section{Fe'ilātün Fe ilātün Fe'ilātün Fe'ilün}

1. Yine ol māh bugün mihrini iẓhār eyler

Șubh tek gün yüzini mațla‘-1 envār eyler

2. Geh meh-i nev gibi merdüm gözidin mahfi olur

Gāh hūrşīd yüzin ḩalḳa nümūdār eyler

3. Kara zülfi baş açıp cilve ḳılur mihr üzre

Ġālibā gün yüzin ol ebr-i siyeh tār eyler

4. Kim ki dil baǵladı zülfine o tersā-beçeniñ

Anı dinden çıkarı māil-i zünnār eyler

5. $\quad$ Ġamze tịgigin ele alıp o gelen yāri görüñ

Ki ne peydā diler ol ẓālim-i hūun-h̆̌ār eyler

6. Elem-i hicr ile kan oldı gönüü anı̃ içün

Dem-be-dem dīde-i giryānımı hūn-bār eyler

7. Çeşm-i hūn-bārımı ḳan dutdı budur vechi anıñ

Ki göñül rāzını her merdüme iẓhār eyler

8. H Haste Ḥammādıñı rüsvā-yı cihān itme didim

Didi ol yār meger ‘āşık olan ‘ār eyler

\section{$12^{4}$}

1. Mestāne-yi 'aḳl u hūşdan dūruz biz

Rindāne-yi mey-i 'aşḳla maḩmūruz biz

2. Sensin bize makșūd iki ‘ālemden

Ney țālib-i ḳașr u cennet ü hūruz biz

3. Var yoḳısa ihtiyācımız hergiz

Faḳr ile zamāne içre meşhūruz biz

Gazelin beyit ve mısralara göre vezni şu şekildedir: 1.beyit 1.mısra, 3.beyit 1.mısra, 6.beyit 2.mısra "Mefūlü Mefā'ilün

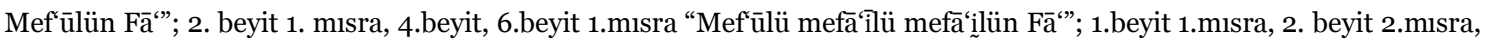

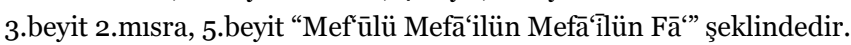

\section{Adres Address}


4. Virān görünür ș̣ūretimiz zāāhirde

Ma'nāda göñül kişveri ma'mūruz biz

5. Dünyāda hemīn şikestelikdir işmiz

Bì-kuvvet ü nā-tüvān u bī-rūzuz biz

[15b]

6. Hammād-ṣıfat miḥnet ü gam miskīiniz

Dā’im elem-i ‘aşkla rencūruz biz

13

\section{Fā‘ilātün Fā‘ilātün Fā‘ilātün Fā‘ilün}

1. Pür-ṣadā eyler șala nāle birle her nefes

Bir hevādan ney gibi ḩālī degül gūyā ceres

2. Ben esīr-i künc-i hicrān yār ag̉yār ile yār

Hem-dem-i zāg̀ oldı gül bülbül giriftar-1 ḳafes

3. Șanma hatț ol la'l ețrāfında yariñ cem`olan

İttifāk ile yüz urmuş şekkere mūr $[u]$ meges

4. Bülbül-i dil-ḩasteniñ feryād-ı zārından șaḳın

Olma ey gül munca dā'im hem-nişīn hāa u has

5. Kākülüñ tārını dār it gamze tīgin al ele

Eylesem kaț ${ }^{\natural}-1$ muhabbet $h^{`} \bar{a} h$ as $[u] h^{` a ̄ h}$ kes

6. Hāṣıll-1 ömr-i revān naḳdin saña șarf itmesem

Bulmasın dünyāda zinde cānım ey cān bir nefes

7. Bir kemīne çākerimdir āsitānımda didiñ

Kemterīn Ḥammāda ancak eyle bu bir nükte bes

14

\section{Fe'ilātün Fe'ilātün Fe'ilātün Fe'ilün}

1. Yüzüñ ey mug̉beçe reşk-i meh-i tābān olmuş

‘Ārıżıñ ġayret-i hūūşīd-i dırahşs̄ān olmuş

2. Gül-i ruhsāāınıñ ețrāfda yetmiş hațt-1 sebz

‘Andelīb-i dil içü[n] țurfe gülistān olmuş

3. Kāmetiñ hasretidin gülșen ara serv-i çenār

Bir bir ilen çekişip dest ü girỉbān olmuş

4. Murg்-1 dil dem-be-dem āh eyler ü bilmez şeb ü rūz

Gül yüz[i] ḥasretidin bülbül-i nālān olmuş

RumeliDE Dil ve Edebiyat Araşttrmaları Dergisi Osmanağa Mahallesi, Mürver Ciceği Sokak, No:14/8 Kadıköy - İSTANBUL / TÜRKIYE 34714 e-posta: editor@rumelide.com tel: +90 505 7958124, +90 2167730616
Address

RumeliDE Journal of Language and Literature Studies Osmanağa Mahallesi, Mürver Çiçeği Sokak, No:14/8

Kadıköy - ISTANBUL / TURKEY 34714

e-mail: editor@rumelide.com

phone: +90 505 7958124, +90 2167730616 
[16a]

5. Göreli şem‘-i ruhuñ gör ki bu pervāne göñül

Ne yanıp āteş-i 'aşḳıñ ile biryān olmuş

6. Seyl-i eşkiñden olur merdüm-i 'ālem ḳamu gark

Çeşme-i çeşmimi gör kim niçe 'ummān olmuş

7. Buldı dil ile ġam-ı 'aşḳ̂n ile cāna ḩarāb

Ki degül ḳābil-i ta'bīr bu vīrān olmuş

8. Ġam degül müdde‘i ger hamdıñ inkār itse

Ki bu Ḥammād anıñ is bātına burhān olmuş

15

\section{Fe 'ilātün Mefā‘ilüun Fe'ilün}

1. Sevmişim bir nigār-1 hū̄o-1 havāṣ

Dil-ber-i nāzenīn ḩāṣsül'l-ḥāṣ

2. Özi insān u ṣūreti hūūī

Şekli maṭbū' u hoş ferişte ḩavāṣ

3. Bağteten bāne ḥabbe fi'l-bāl

Ḳad ta'aşşaḳtu 'ani'l-iḩlāṣ

4. Tereke'l-ḳalbu ḥubbe mā-ġayruh

Mālun bi-ebīi ileyh min-eşhāṣ

5. Bir kemān-dār tīrden geh ayurur

Aña şākird-i Sa'd bin Vaḳḳaṣ

6. Çāpük ü cüst düşer girü dil-ber

Pehlevān-ı cihānda vü raḳạaṣ

7. İbnü 'amm-ı resūl kim anı ḥak

Baḥr-1 şer‘ içre eylemiş ġavvāṣ

8. Velīi hak u hayy-1 peygamber

Muḳtedā-yı 'avām nās u ḩavāṣ

9. Kirdgār bi-ḥaḳk - şāh-1 Necef

Eyle iḥsān țarịk-i istihlāṣ

[16b]

10. Ḳoyma baḥr-ı elemde Ḥammādı

Varța-i ġamdan eyle anı ḩalāṣ 


\section{Fā‘ilātün Fā‘ilātün Fā‘ilātün Fā‘ilün}

1. Hasbeten-li'llāh ṣabā derd-i dilim ḳıl yāre ‘arż

Eyle bir bir şerḥ-i aḥvālim benim dil-dāre ‘arż

2. Rū tutup gūyā dilim țūtî gibi lāl oldugưm

Ḥasret-i la‘l-i lebinden ol şeker-güftāre 'arż

3. 'Andelībā ne dem-ā-dem nāle-i efḡānımı

Şükrüñ içün eyle ol ruhsāresi gülzāre ['arż]

4. S Sarșar-1 hicrān gubār-1 cismim efşān itdigün

Zerre-sān bād-1 șabā ḳıl ol güneş ruhsāre 'arż

5. Şām-1 hicrān isterim vașl ile kim cennet diler

Eylegeç rūz-1 kıyāmet dūzah ehlin nāre ‘arż

6. Leşker-i gam eyledi tārāc göñlüm şehrini

Āh kim feryād işitmez eylesem serdāre ‘arż

7. Eylerem Ḥammād bir gün yaḳa yırtıp dād idip

Ol sitemger yār elinden ben sipeh-sālāre 'arż

17

\section{Fā‘ilātün Fā‘ilātün Fā‘ilātün Fā‘ilün}

1. Ey dil esbāb-1 ta'alluk ḳaydıdan kes irtibāt

Āhiret fikrin gözet dünyā evinden yığ bisāṭ

$[\ldots]^{5}$

18

\section{Fā‘ilātün Fā'ilātün Fā'ilātün Fā'ilün}

$[\ldots]^{6}$

1. Hoş idip sā’irin elden ele virmege müdām

Sākīi-i mehveş pey-ā-pey baş açıp șunmak ayağ

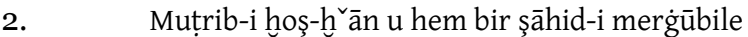

Seyr-i gülzār eylemek ag̉yār çeşminden ırag்

3. Yār-1 gül-rū birle ḳılmak dem-be-dem hoş ihtilāt

Lāle tek ḳılmaḳ müdām ag̉yār bağrın dāg̀ dāg

4.

Ehl-i ‘isyānem diyü Hammād olma bā-ümīd

$5 \quad$ Nüshada 17 numaralı gazelin matla beyiti olarak yazılmıştır. Müstensihin aldığı yerde şiirin eksik olduğu ya da metni istinsah ederken dikkatsizlikle iki şiiri birleştirdiği düşünülmektedir. Müstensih kaynaklı bir hata olduğu düşünülerek gazeller tek bir gazel numarası altında verilmemiştir. Nüshada 17 numaralı gazel ile birleștirilmiștir.

RumeliDE Dil ve Edebiyat Arașturmaları Dergisi Osmanağa Mahallesi, Mürver Ciçeği Sokak, No:14/8

Kadıköy - İSTANBUL / TÜRKIYE 34714

e-posta: editor@rumelide.com

tel: +90 505 7958124, +90 2167730616
Address

RumeliDE Journal of Language and Literature Studies

Osmanağa Mahallesi, Mürver Çiçeği Sokak, No:14/8

Kadıköy - ISTANBUL / TURKEY 34714

e-mail: editor@rumelide.com

phone: +90 505 7958124, +90 2167730616 
Āyet-i lā-taḳnaṭū mażmūnına dutgil ḳulag̉

[17a]

19

\section{Fā'ilātün Fā'ilātün Fāilātün Fā'iliun}

1. Eşk-i mercāndır leb-i la liñ dişiñ dürr-i Necef

Lü’lü'-i şehvār-1 güftārın aña ağız șadef

2. Naḳd-i cān virdim yoluñda ey büt-i sīmīn-beden

Ḥāṣıl-1 ‘ömr-i şerīf itdim saña bir bir telef

3. Seng-i cevr ilen benim sındırma göñlüm şişesin

Kim leb-ā-leb hūndur mey sāgaarı tek bu ḩazef

4. Bes ki ey gül-rū beni yandırdı hicrānıñ odı

Lālezār oldı vücūdum dāğı birle her țaraf

5. $\quad$ Sinem üzre her birin etmiş revān bir cūy-1 hūun

Zaḩm-1 peykān-1 ḩadengiñ kim düzimiş șaf-be-șaf

6. Her ne ok kim ol kemān-ebrū atar cān kașdına

Cān sinān peykānlar içün levḥ-i sīnemdür hedef

7. Ben de Ḥammādım sipāh-ı gamda tenhā vü garīib

İsterim senden himāyet eyle yā șāh-ı Necef

20

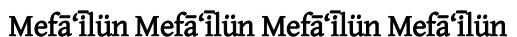

1. Leb-i cān-bahşıñ ister haste cāniçün devā ‘āşı

Mariż-1 'aşḳdır bilmez nedir dārü’ş-şifā ‘āşık

2. Çü derd-i 'aşḳa yoḳ bir çāre ger yüz biñ țabīb olsa

Ne tedbīr eylesin n'etsin ne ḳılsın bī-nevā ‘āşık

3. Ża '̇if olmuş ten-i bīmār u cān yok haste cismimde

Olurmuş nā-tüvān ger olsa cānāndın cüdā 'āşık

4. Ḳanı āsān șanurdum ben belā-yı 'aşḳıñ ammā

Ne müşkil derd imiş bildim olan sa'āt saña ‘āşık

5. $\quad$ Bu şekl ü șūret-i hūūbılla ger 'arż-1 cemāl itseñ

Olur ey server-i hūbān saña şāh u gedā 'āşık

6. Durup her laḥza devr eyler cihānı bir dem eg̉lenmez

Ṣanasın bir güneş ruhsāradır bād-ı șabā ‘āşık

7. Göñül Hammādıñ incimese ger cevr itse dil-dārıñ

\footnotetext{
Adres $\mid$ Address

RumeliDE Dil ve Edebiyat Araşttrmalar Dergisi Osmanağa Mahallesi, Mürver Ciçĕgi Sokak, No:14/8 Kadıköy - İSTANBUL / TÜRKIYE 34714 e-posta: editor@rumelide.com RumeliDE Journal of Language and Literature Studies Osmanağa Mahallesi, Mürver Çiçeği Sokak, No:14/8

Kadıköy - ISTANBUL / TURKEY 34714

e-mail: editor@rumelide.com

tel: +90 505 7958124, +90 216773 o 616 phone: +90 505 7958124, +90 2167730616
} 
Ki cānāndın bulur geh cevr geh mihr ü vefā ‘āşık

[17b]

21

\section{Fā'ilātün Fā'ilātün Fā‘ilātün Fā‘ilün}

1. Ey melek gülzār-1 hüsnüñ bāg̀-1 rıdvāndır seniñ

Ārzūmend-i cemāliñ hūr u ğılmāndır senin

2. Sen güzeller serveri hem hūblar sultān̄ısın

Cümlesi hükmünde ey şeh bende fermāndır senin

3. Gülşen-i nāz içre her sū 'azm-i seyrān eylegeç

Kāmetiñ ey serv-i ra‘nā ḩoş-ḩırāmāndır senin

4. Bāg ara bir seyr ḳıl ol nergis-i şehlānı gör

Kim göz açmış çeşmiñe bī-çāre ḥayrāndır senin

5. $\quad$ Tā ki vașlıñdan cüdā düşdüm aluşdım odlara

Bu dil ü cān āteş-i hecriñde sūzāndır senin

6. Her seher kūyuñda efgān eyleyen bülbül degül

Ey gül-i nevreste bu Ḥammād-ı nālāndır seniñ

22

\section{Fā'ilātün Fā'ilātün Fā‘ilün}

1. Ey cemāli māh-1 tābāndan güzel

‘Ārıżı mihr-i dırahşşāndan güzel

2. Dişleri lü’lü'-i ter aǵzı șadef

Lebleri la'l-i Bedehşāndan güzel

3. $\quad$ Bir nihāl-i tāzedir şimşādıñ

Kạametiñ serv-i ḩrāmāndan güzel

4. Nūr-1 ruhsāânındır ey vechi ḳamer

Meş‘al-i şem'-i şebistāndan güzel

5. Pertev-i bedr-i ruhuñundur şām-1 vaṣl

Āfitāb-1 rūz-1 hicrāndan güzel

6. $\quad$ Ey periveş ādem olmaz sen gibi

Bir meleksin ḥūr u ġılmāndan güzel

7. Reşk-i cennetdir ser-i kūyuñ seniñ

Bārgāhıñ bāğ-ı rıdvāndan güzel 
8. B Bī-zebān Ḥammādam itdim vaṣfıñı

Hoş feșāḥat birle Ḥassāndan güzel

[18a]

23

\section{Fā‘ilātün Fā'ilātün Fā'ilātün Fā'ilün}

1. Yār gö[r]geç raḥm ḳılmaz çeşm-i giryānım benim

Bir telattufuf eylemez bī-rahm cānānım benim

2. Aġlarım ben dem-be-dem eyler tebessüm gonce tek

Ol gül-i ḩandān görüp çāk-i perişānım benim

3. Küfr-i zülfinden dil-i āşüfte fāriğdir velī

Gör ne cevr eyler baña ol nā-müselmānım benim

4. Ağlamaḳdan āteş-i fürḳatde iden muttașıl

‘Ālemi ġark itdi çeşm-i eşk-efşānım benim

5. Büt-perest oldum reh-i 'aşḳıñda ey tersā-beçe

Küfre tebdīl oldı ahir dīn [ü] imānım benim

6. Ārıżiñ üzre haț u hāâliñ ki düşmüşdür raḳam

Eylerim ezber budur gūyā ki Kur'ānım benim

7. Hīç șormaz hālim ol Leylī-șıfat bir kez dimez

Kim gedā Hammāddır Mecnūn-ı ‘uryānım benim

24

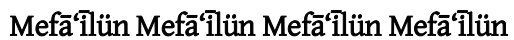

1. Aġardı göz göñül oldı mükedder beyt-i ahzāndan

Șabā başıñçün olsun bir ḩaber vir māh-1 Ken‘āndan

2. Baña mațlūb cānāndır gel ey zāhid firỉbiñle

Dem urma bāg̀-1 rıdvāndan cemāl-i hūūr u ġılmāndan

3. Gönül meyl eylemez cānā dahı̆ seyr-i gülistāna

Temāşā-yı cemāliñ fārig itmiş bāg u bustāndan

4. Yüzüñ hūrōsīd-i rahş̧āndır mukavvesdir seniñ ey meh

Kaş̧ı̃ ḳavs-i feraḥdan hem hilāl-i ‘ydd-1 kurbāndan

5. Mesịh i'cāzı tek her dem ḳılur yüz mürdeni zinde

Leb-i yuhyi'l-'izāamuñ kim eleżdür āb-1 hayvāndan

6. Belā-yı 'aşk ilen cānā besi zār u ża'îif olmuş

Yazukdur iltifatıñ kime bu Ḥammād-ı bī-cāndan 


\section{Mefā'î̀ün Mefā'îlün Mefā'î̀ün Mefā'îilün}

1. Humārım def'in it sākī tegāaül ḳılma deryāda

Elim dut bir ayağlayın şarābı dönme mīnāda

[18b]

2. Mey içmek yahşidir rindāne bu devr içre ey zāhid

Müdām olmak yamandır hem-dem-i tesbīh ü seccāde

3. Saña zāhid dimiş kim hūra beñzer ol perī-peyker

Görüm şermenden olsun ben anı dünyā vü ‘ukbāda

4. Seniñ bu şīive-i nāz ile nāzik kāāmetiñ görgeç

Ḥayā ḳılmaz mı yā Rab beñzedin serv ile şimşāda

5. Seniñ şirīn şeker ḳandıñ gören ey husrev-i hūbān

‘Acebdir mi meni mānend oḳur şūrīde Ferhāda

6. Çıardım haste cismimden ser-i zülfüñde bend itdim

Bi-ḥāmdi'llāh ki cān ḳaydından āḩir oldum āzāde

7. G Garīb ü hāksāar u müstemend ü nā-tüvānıñdır

Gel ey zạalim yeter cevr itme bu bī-çāre Ḥāmmāda

26

\section{Fe ilātün Fe ilātün Fe ilātün Fe ilün}

1. $\quad \bar{A}$ rzū-yı leb-i meygūnuñ ilen ey gül-rū

Kāse-i dīde kızıl kanıla oldı memlū

2. Mey gibi gerdeni zincīrde sen Leylīi içün

Gezerim her yaña Mecnūn gibi ben ḳapu ḳapu

3. $\quad$ Düşdi dilden dile ey şūh cemāliñ żikri

Oldı āvāze-i hüsnüñ bile āfāk dolu

4. Dane dane düzilen ‘ārıżıñ üzre ey gül

İncü tek sö[y]le ki şebnem mi irür yā lü'lü'

5. Yel esip deprediçüñ gīsū-yı müşk-efşānıñ

Ser-be-ser 'ālem olur ḩoş ḳoḳudın 'anber-bū

6. Kākülüñ dāmide bend itmege 'āşık göñlüni

Zü-fünūn gözleriñ ey şūh ḳılur pür cādū

7. Ser-i kūyuñda çenār baş başa üftādeleriñ

‘Aşk zincīine pā-bestedir anlar ḳamu 
8. Ș̣ıfat-1 hüsnüñi ḳıldım baña bir būse didim

Didi Ḥammād yeter bunca ne mehrbāndır bu

[19a]

27

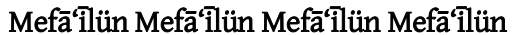

1. Benim bir nāzenīn ġonçe-dehen hoş-lehce yārim var

Benefșe-hyatț gül-rū serv-kad zībā nigārim var

2. Eger var ise rıḍānıñ behişti içre hạāāisi

Bi-ḥamdi'llāh benim hem bir perī-ruhsāâr yārim var

3. Yeter ey Hुıżra yoktur ị̣tiyācım āb-1 ḥayvāna

Zülāl-i la'l-i dil-ber gibi āb-1 hoş-güvārım var

4. Beni ey men“ iden gāâfil reh-i 'aşḳından ol yāriñ

Meger eyle șanursın kim elimde ihtiyārım var

5. Açılmış dāğ-1 hicrāndan ḳızıl güller temāşā ḳıl

Ki șaḥn-1 sīne-i sūzān ara ḩoş lālezārım var

6. Cihān esbābıdın yok bundan artuk māl mülk ancak

Dil-i mecrūḥ cān-ı haste vü cism-i figārım var

7. Şefi' 'ül'-müznibīnā çekmezem gam havl-i mahşşerden

Ne fikrim var ki sen tek bir şefi'-i gam-küsārım var

8. Ümīiniñ kesme ey Ḥammād-ı bī-cān luṭf-ı Yezdāndan

Ki luṭf-1 Kirdgār-1 ‘ālemine intiẓārım var

28

\section{Fā'ilātün Fā'ilātün Fā'ilātün Fā'ilün}

1. Serv garralanmasın öz kāamet-i bālāsına

Kim ḳılur nisbet anı yāriñ ḳad-i zībāsına

2. Neyleriz biz gülşeni kim gül yüzüñ besdir bize

Bāḡbān faḩr itmesin çoḳ ol gül-i ḥamrāsına

3. $\quad$ Nergise bahduḳda düşdi şūh çeşmiñ yādıma

Sünbüli gördükde düşer zülfleriñ sevdāsına

4. Bunca kim dürdāneler tek göz yaşı andan çıkar

N’ola germ-hūsun disem bu çeşminiñ deryāsına

\footnotetext{
Adres $\mid$ Address

RumeliDE Dil ve Edebiyat Arașttrmaları Dergisi Osmanağa Mahallesi, Mürver Ciçĕgi Sokak, No:14/8 Kadıköy - İSTANBUL / TÜRKIYE 34714 e-posta: editor@rumelide.com RumeliDE Journal of Language and Literature Studies Osmanağa Mahallesi, Mürver Çiçeği Sokak, No:14/8

Kadıköy - ISTANBUL / TURKEY 34714

e-mail: editor@rumelide.com

tel: +90 505 7958124, +902167730616 phone: +90 505 7958124, +90 2167730616
} 
5. $\quad$ Ülfetiñ āyīne-i dil jengini ger açmasa

İdebilmez yüz bu șayḳal çāre gönlüm pāsına ${ }^{7}$

[19b]

6. Didiler Hammād ölüpdür yār işitgeç bu sözi

Didi kim kimiñ gerek ol bī-nevānıñ yasına

29

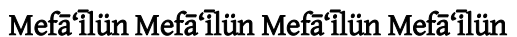

1. Baña 'aşkı̃ñ yolında Ḳays-ı bī-pervā ne nisbetdir

Saña bu hüsn ile ey nāzenīn Leylā ne nisbetdir

2. Lebiñ bağrın hasedden ḳana döndürdi mey-i nābuñ

Zülāl-i çeşme-i ḥayvānıña șahbā ne nisbetdir

3. Cemāliñ kim meh-i hūurşīi ey gül şermsār eyler

Aña ḥüsn-i lețāfetde gül-i ḥamrā ne nisbetdir

4. 'İzārıñ pertevin ḳıldı siyeh haț̣tı̃ 'acebdir bu

Teḳārun eylemek mihre şeb-i yeldā ne nisbetdir

5. Lebiñ vașfinda olmuş țūtî̀-i țab'ım şeker-efşān

Baña vașf-1 ruhuñnda bülbül-i gūyā ne nisbetdir

6. Kadin Ṭūbāya dil-dārıñ müșābih dir imiş zāhid

Bütün nā-ehle bilmen nisbet-i bī-cā ne nisbetdir

7. Sözin bilmezleri gör kim özin şāiir șanur her dem

Kalur Ḥammād nisbet cehlile ammā ne nisbetdir

30

\section{Fā‘ilātün Fā'ilātün Fā'ilātün Fā‘ilün}

1. Zülf-i āşüfteñ seniñ kim fitneciler başıdır

Çeşm-i fettānıñ seniñ ey şūh baş yoldaşıdır

2. Nāz-1 gamzeñ birbire benze[r] seniñ cān almada

Bu anıñ ḳızḳardaşı yā ol bunun ḳardaşıdır

3. Server olmuşdur sipāh-1 hüsnüñe gördüm ḳara

Kākülüñ serdārı iki ey gözim yüzbaşıdır

4. $\quad$ Ney musavversin ki tașīir idebilmez șūretiñ

Hīç vechile seniñ Mānī ki Çīn naḳkāşıdır

Nüshada “İdebilmez yüz saykal çāre bu gönlüm pāsına” șeklinde olup vezin gereği "bu” yeri değiștirilmiștir. 
5. $\quad$ Mey gerekdir içmege ben bilmezem yahş̧i yaman

Hูª̄n anıñ țarfi ḳabaḳ yā sifāl kāşīiir

[20a]

6. Dāğlar zahmın ḳalur gögsümde gün günden füzūn

Sīnem üzre çaldukum bilmen ne dāğıñ daşıdır

7. Öz gözümdendir benim ruhsār-1 yāri görmemek

Māni'-i dīdār olan Ḥammād çeşmim yaşıdır

31

\section{Mef'ūlü Mefā'î̀ü Mefā'î̀iü Fe‘ūlün}

1. Bu dehr-i sitemgerde ki bünyāda gelipdir

Kim der ki ġam [u] guușṣadın āzād[e] gelipdir

2. Ey pādişāhım ne mūrlayın eyle teraḥhum

Bu bendeye kim dergehiñe dāda gelipdir

3. Sen yine ile ser-hoş [u] men naḳd ile mestem

Zāhid saña Kevs er baña ḩoş bāde gelipdir

4. G Gūyā ki gül-i 'ārıżıñ bāde getürmüş

Bülbül gibi göñlüm ḳuşı feryāda gelipdir

5. Bu hüsn ile cānānıma insān dimek olmaz

Evșāf-1 melā’ik o per[i]-zāde gelipdir

6. Her lāf idene 'āşık-1 șādık dimek olmaz

'Āşı ḳlı̣ işi șılḳile Ḥammāda gelipdir ${ }^{8}$

32

\section{Mef'ūüü Mefā'î̀ün Mef'ūüü Mefā'î̀ün}

1. $\quad$ Ey hāāk-i pāyıñ 'ālem başınıñ tāci ${ }^{9}$

Her şāh [u] gedā anıñ bir zerr[e]si muḥtācı

2. Luṭf-ı kerem itdi hạak kim ḳıldı bize mürsel

Mecmū'-1 nebīlerden bir sen bigi yalvācı

3. Terk-i dil [ü] dīn itdim dutdum reh-i 'aşḳını

Heftād [u] dü milletde[n] çı̣̂dım ki olam nācī

4. $\quad$ Ey şūh్h-1 kemān-ebrū at ġamzeñ oḳın bir bir

Bu sīne-i mecrūhum olsun anıñ ammācı

Nüshada “Āşıḳlı̣̣ işi șıdḳile ancaḳ Ḥammāda gelipdir” şeklinde olup vezin gereği “ancaḳ” yazılmamıştır. Vezin kusurludur.

Adres

RumeliDE Dil ve Edebiyat Araştırmalar Dergisi Osmanağa Mahallesi, Mürver Çiçeği Sokak, No:14/8

Kadıköy - İSTANBUL / TÜRKIYE 34714 e-posta: editor@rumelide.com

tel: +90 $5057958124,+902167730616$

\section{Address}

RumeliDE Journal of Language and Literature Studies

Osmanağa Mahallesi, Mürver Çiçeği Sokak, No:14/8

Kadıköy - ISTANBUL / TURKEY 34714

e-mail: editor@rumelide.com,

phone: +90 505 7958124, +90 2167730616 
[2ob]

5. $\quad$ Meygūn lebiñ ey gül-rū yüz ța‘ne ḳılur la‘le

Reşk-i dür-i dendānıñ dil tīre ḳılur ‘ācı

6. Eyyā[m]-1 viṣāliñde āsūde iken göñlüm

Dil şehrini hicrānıñ șaldı gine tārācı

7. Dām-1 ser-i zülfüñnde bend oldı göñül

Şehbāz-ı nigāhıñ ḩoş șayd itdi bu alacı

8. Şirīn lebine yāriñ şeker didim incindi

Türkāne messeldir bu doğrı söz olur acı

9. Bu dehr bisāțında egleşmedi naḳşım ḩoş

Dönsün göreyim çarḩı öldürmelü leylāc1

10. Mahşer güni ey server Ḥammādı getür yāde

Ol mücrim-i bì-çāre iḥsāniñadur rācī

33

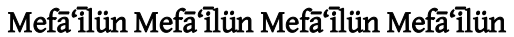

1. Egerçi nāzenīn hūūb-rū maḳbūl dil-bersin

Velīkin ehl-i ‘aşka cevr iden zā[lim] sitemgersin

2. Cebīniñ mațla'-1 mihr-i sa'ādetdür gözim nūrı

Bu şekl ü hüsn-i ‘ālem-tāb ile hem mihr-i enversin

3. Saña insān dir her kimki insān neslidir zīrā

Ferişte-țāl'at u ġ̀lmān-şemā’il ḥūr-peykersin

4. 'Aceb nāz u nezāket verd-i nihāl serv-i ḳaddiñe

Bu ḳadd u ḳāmet-i mevzūnile reşk-i șanavbersin

5. Ötersin yan virip bizden nedir ey bì-mürüvvet sen

Dimezsin luṭfila Ḥammāda ḩoş geldiñ ne istersin

\section{Müseddes}

I

Mef ūlü Mefā'î̀ü Mefā'î̀ü Fe'ūlün

Şükr itdi bahār oldı hazān gitdi zevāle

Açıldı çemen içre gül ü sūsen [ü] lāle

[21a]

Gül bergine baḳdırdı șabā ḳatre-i jāle

Bu mevsim-i şāyeste gerek rāh-1 dü sāle 
Doldur içelim sāḳīi gül-çehre piyāle

Ḳoyma yazuḳum kim ġam-ı devrān beni ala

II

Ey muțrib-i hoş-ȟ̉ ān çala gör çeng [ü rebābi]

Minnet bilüben bir nice gün vaktt-i şitābı

Dutma ḳadehi sahlama mīnā vü şarābı

Gel başuñ içü[n] güzerdür mey-i nābı

Doldur içelim sāḳ̄i-i gül-çehre piyāle

Ḳoyma yazuḳum kim ġam-1 devrān beni ala

III

Gülzār-1 cihān olmuşisen ‘amd-ı cennet

Billāh ne münāsib görünür yār ile ülfet

Ṣaḥn-1 çemen ü hem-dem-i hoş meclis-i halvet

Düşmez ele ta'līl ile fevt ile firṣat

Doldur içelüm sāḳīi gül-çehre piyāle

Ḳoyma yazukum kim gam-ı devrān beni ala

IV

Gül fașl[1] getür yādıña eyyām-ı hazānı

Bah gör ki niçe ḳaldı vefā ‘ālem-i fāni

Vir bādeyi terk eyleyelim fikr-i cihānı

Ser-mest oluben bilmeyelim yahşsi yamanı

Doldur içelim sāḳī-i gül-çehre piyāle

Koyma yazukum kim gam-1 devrān beni ala

[21b]

V

Hāṭ̂rda gam-1 gusș̣a-i derd oldı hüveydā

Dil memleketin leşker-i ġam eyledi yağmā

Ġam jengi göñül gözgüsini dutdı ser-ā-pā

Yā șāf ide dil āyīnesin cām-1 mușaffā

Doldur içelim sāḳ̂i-i gül-çehre piyāle

Koyma yazukum kim gam-ı devrān beni ala

VI

Ḥammād renc-i humār eyledi dilgīir ${ }^{10}$

Ḳ1l gel aña bir cām-1 ferāḥ-bahş ne tedbīr

10 Vezin kusurludur.

RumeliDE Dil ve Edebiyat Araştırmaları Dergisi Osmanağa Mahallesi, Mürver Ciçeği Sokak, No:14/8 Kadıköy - İSTANBUL / TÜRKIYE 34714 e-posta: editor@rumelide.com tel: +90 505 7958124, +90 2167730616
Address

RumeliDE Journal of Language and Literature Studies Osmanağa Mahallesi, Mürver Çiçeği Sokak, No:14/8

Kadıköy - ISTANBUL / TURKEY 34714

e-mail: editor@rumelide.com

phone: +90 505 7958124, +90 2167730616 
Kurbānıñ olam ${ }^{11}$ sö[y]leme munca bu te'hīir

Fırșat var iken elde gözüm eyleme takṣīir

Doldur içelim sāḳi-i gül-çehre piyāle

Ḳoyma yazuḳum kim ġam-1 devrān beni ala

\section{Kaynakça}

Çalka, M. S. (2014). Klasik Türk şiirinde rubâî. Yayımlanmamış doktora tezi, Atatürk Üniversitesi Sosyal Bilimler Enstitütüsü, Erzurum.

Hammâd. Dîvânçe. Yapı Kredi Sermet Çifter Araştırma Kütüphanesi, Nadir ve Yazma Eserler Bölümü, 035771/1.

Köksal, F. (2017). Eski Türk Edebiyatında Tenkit ve Teori. İstanbul: Kesit.

Tâhirü’l-Mevlevî (2019). Edebiyat lügatı. (haz. Kemâl Edîb Kürkçüoğlu). İstanbul: Büyüyenay.

Ünver, İ. (1993). Çevriyazıda yazım birliği üzerine öneriler. Ankara Üniversitesi DTCF Türkoloji Dergisi, C XI, S 1, s. 51-89.

\section{Örnek metinler}
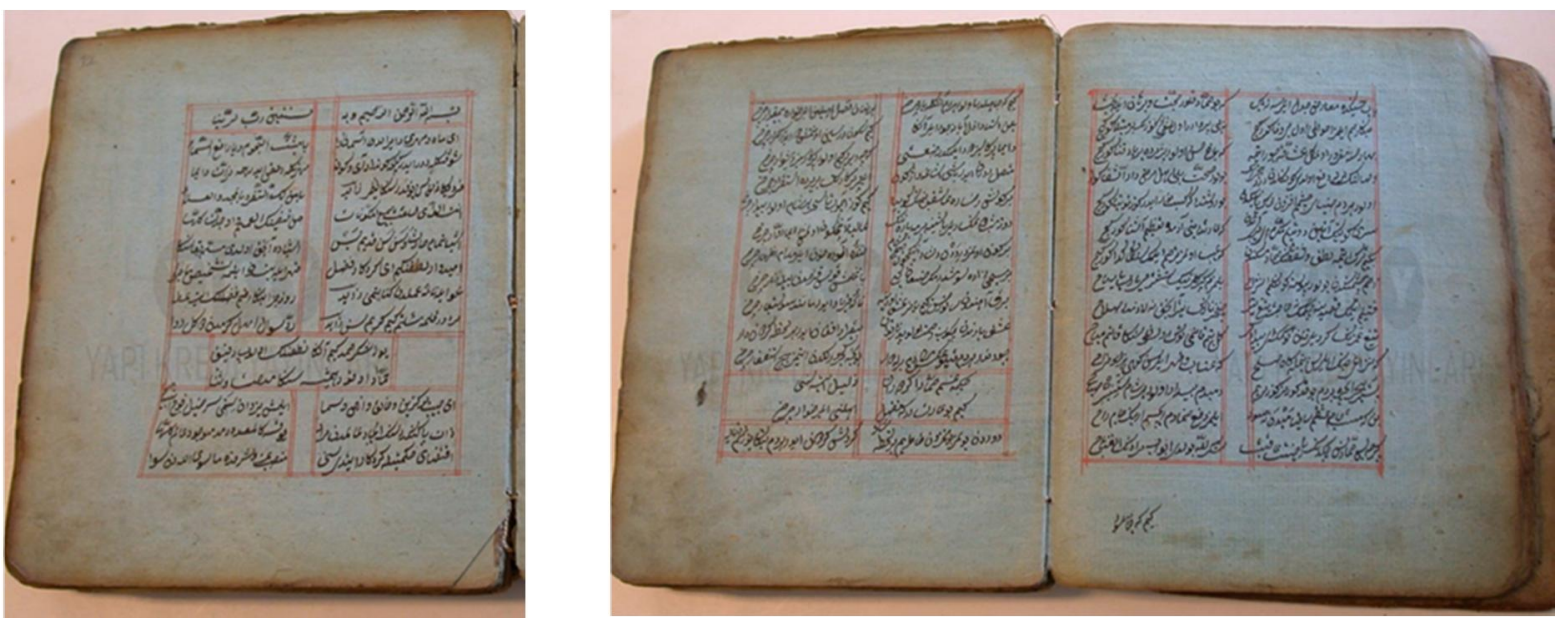

Nüshada “ولولوم" şeklinde imlalanmıştır ancak anlam gereği “olam” şeklinde okunmuştur.

Adres | Address

RumeliDE Dil ve Edebiyat Araştırmalar Dergisi Osmanağa Mahallesi, Mürver Ciceği Sokak, No:14/8

Kadıköy - İSTANBUL / TÜRKIYE 34714 e-posta: editor@rumelide.com

RumeliDE Journal of Language and Literature Studies

Osmanağa Mahallesi, Mürver Çiçeği Sokak, No:14/8

Kadıköy - ISTANBUL / TURKEY 34714

tel: +90 $5057958124,+902167730616$

e-mail: editor@rumelide.com

phone: +90 5057958124 , +90 2167730616 
640 / RumeliDE Journal of Language and Literature Studies 2021.22 (March)

An unknown poet: Hammad and his Divanche / E. Tok (pp. 616-640)
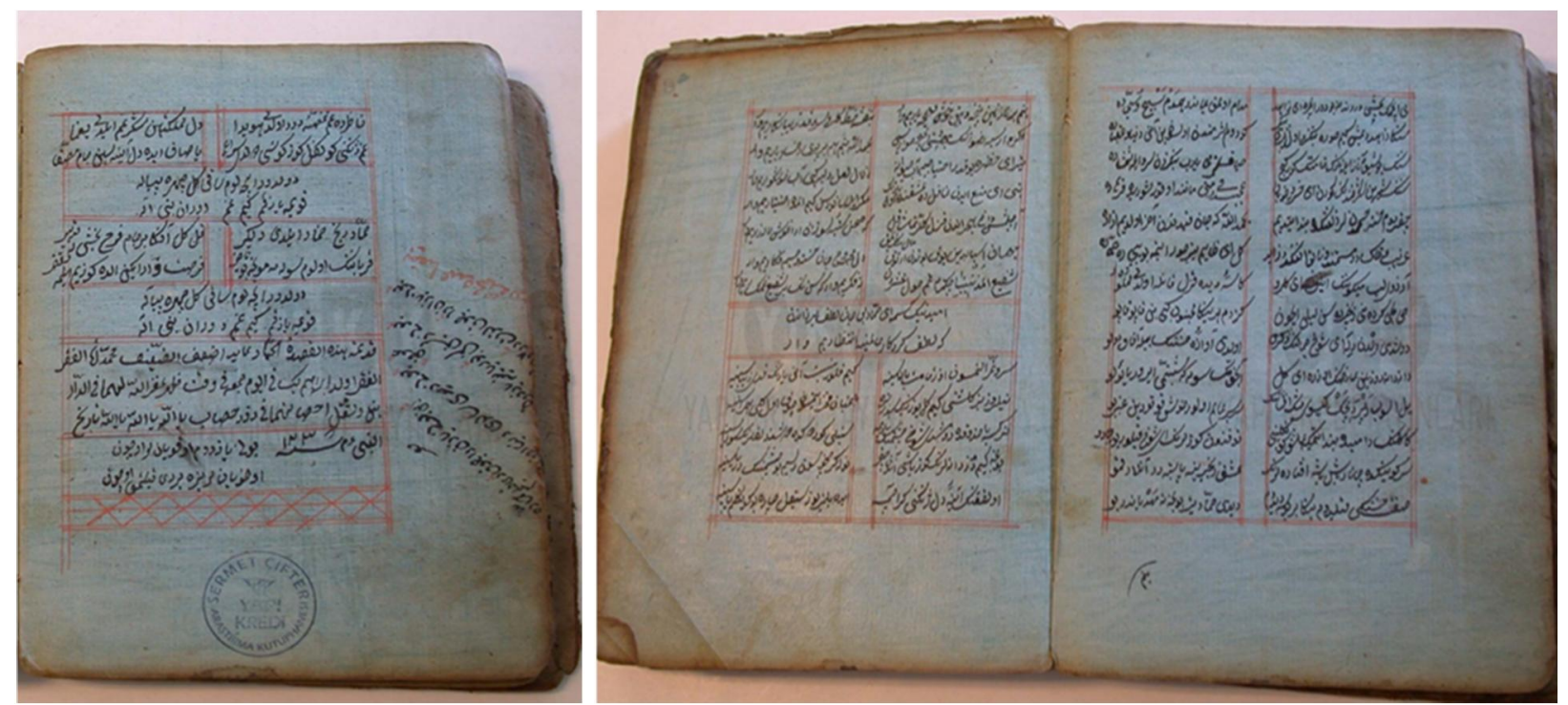

Adres

RumeliDE Dil ve Edebiyat Araștırmalar Dergisi Osmanağa Mahallesi, Mürver Çiçeği Sokak, No:14/8

Kadıköy - ISTANBUL / TÜRKIYE 34714 e-posta: editor@rumelide.com

tel: $+905057958124,+902167730616$
Address

RumeliDE Journal of Language and Literature Studies

Osmanağa Mahallesi, Mürver Çiçeği Sokak, No:14/8

Kadıköy - ISTANBUL / TURKEY 34714

e-mail: editor@rumelide.com,

phone: +90 $5057958124,+902167730616$ 